WHY ARE SELF-HELP BOOKS WITH CAREER ADVICE FOR WOMEN POPULAR?

\author{
Isabel Metz \\ University of Melbourne \\ i.metz@mbs.edu
}

Savita Kumra

American University of Sharjah

skumra@aus.edu

Acknowledgements: We thank our colleagues, Kara Arnold, Marta Calás, Donna Chrobot-Mason, Marianne Cooper, Stella Nkomo and Linda Smircich, who supported us by being panellists at the AOM Symposium that led to this manuscript. We also thank the reviewers and the associate editor, professor Louise Mors, for their invaluable advice. 


\title{
WHY ARE SELF-HELP BOOKS WITH CAREER ADVICE FOR WOMEN POPULAR?
}

\begin{abstract}
Self-help books with career advice for women who aspire to leadership are popular. This popularity is somewhat surprising, in that the advice appears to take us back to the "fix the women' approach to career advancement of the 1960s and 1970s. Sheryl Sandberg's (2013) 'Lean In' book is a vivid example of this popular genre of books. In this paper, we use Sandberg's book to examine why a focus on personal agency is resonating with so many women. We explain the success of 'Lean In' from the working woman's perspective. We compare and contrast the academic and popular literatures. We then reflect on the relevance of individual action as a catalyst for change in relation to the more difficult to change barriers to women's advancement at the interpersonal, organizational and societal levels. We conclude by reflecting on what the popularity of the self-help literature tells scholars about future research directions and the dissemination of their findings.
\end{abstract}

Keywords: Women Leaders, Careers, Self-Help Books, Individual Agency, Lean In 
Women and management research dates back several decades and studies published in this area have increased tenfold in the last 20 years (see Table 1). Yet, questions remain about the causes and processes that persistently exclude women from leadership positions across the globe (Joshi, Neely, Emrich, Griffiths \& George, 2015; Metz \& Kulik, 2014). Further, women's representation in the upper echelons of organizations continues to increase at a slow and patchy rate (Catalyst Quick Take, 2017; Hausmann, Tyson, Bekhouche, \& Zahidi, 2014), with an implicit cap possibly in place (Dezsö \& Ross, 2016). In their quest for answers, scholars have shifted their research focus and practical recommendations over the last 50 years (from 1967-2016 inclusive) away from 'fix the women' to 'fix the environment,' as illustrated in Table 2. The initial emphasis was on women's innate characteristics and socialization processes that explained women's lower career success than men's (e.g., Horner, 1972). This period of scholarship can be called 'fix the women' because the focus was on individual factors, such as women's education, that might have explained gender differences in career outcomes. However, scholars recognized early on that a focus on individual factors did little to alter the aspects that hinder women's career advancement that are outside of their control (e.g., Kanter, 1977; Terborg, 1977), such as organizational structures (e.g., policies and practices) and national elements (e.g., legislation and culture). Thus, over time, research and practical recommendations focussed more on the impact of organizations and societies (e.g., Acker, 1990; Ely \& Meyerson, 2000). This shift has recently led to a focus on men as change agents for gender equity in leadership (e.g., Metz \& Kulik, 2016) and on gender quotas legislation (Seierstad, Warner-Søderholm, Torchia, \& Huse, 2015).

(Insert Tables 1 and 2 about here)

Popular books with career advice for women exist alongside this extensive body of research on women and management. Books in this genre predominantly focus on the individual and 
encourage personal agency. Thus, their popularity is somewhat surprising in that the advice appears to take us back to the 'fix the women' approach of the 1960s and 1970s.

Sheryl Sandberg's 'Lean In' (2013) book is a vivid example of this popular genre. We use 'Lean in' to examine why a focus on personal agency is resonating with so many women and some men (Wallace, 2014). We start by comparing and contrasting the academic and popular literatures. In doing so, we assume the working woman's perspective to explain the popularity of 'Lean In.' We also reflect on the relevance of individual action (proposed in 'Lean In') as a catalyst for change in relation to (the more difficult to change) barriers to women's advancement in the interpersonal, organizational and societal spheres. We conclude by drawing on the popularity of books like 'Lean In' to suggest a research agenda going forward.

\section{A COMPARISON OF THE ACADEMIC AND POPULAR LITERATURES}

As Table 2 illustrates, we conceive three broad 'periods' in women and management literature over the last 50 years $^{1}$. The first period (1967-1976) is characterized by a focus on 'fixing' women through research centred on whether or not women had the necessary human capital or personality to advance in management. Human capital is understood to be the knowledge and skills that people accumulate over time, such as education, company tenure, training and work experience (Becker, 1993). Based on human capital theory, individuals with more human capital are likely to be more productive and, thus, earn 'rewards' such as promotion and better pay.

The focus of research in women and management gradually changed as the gender gap in human capital narrowed, while women's scarcity in leadership remained (Treiman \& Terrell, 1975). Further, early accounts of women's work experiences exposed career barriers that were

\footnotetext{
${ }^{1}$ We explain in the Appendix the literature search method used.
} 
outside of their control (Alexander \& Sapery, 1973; Kanter, 1977). Thus, from 1977 to 1996, research increasingly focussed on understanding the interpersonal (e.g., mentors and networks) and organizational (e.g., policies and practices) factors that affected women's career opportunities (e.g., Chao, Walz, \& Gardner, 1992; Tharenou, Latimer, \& Conroy, 1994). Practical recommendations during this period continued to target women (e.g., women should seek mentors), but increasingly also targeted organizations (e.g., organizations should offer mentoring programs for women). We broadly label this as 'fix the organisation' period.

Some of the evidence acquired during the 'fix the women' and 'fix the organization' periods suggested, however, that much of what happens inside the organization is influenced by what occurs outside of it (e.g., Horner, 1972; Terborg, 1977; Youssef, 1974). For instance, negative perceptions of women as leaders are commonly based on social expectations of women as caregivers and of men as providers (Eagly \& Steffen, 1984). So, while research continues to focus on what women can do to advance (e.g., by cultivating sponsors or raising their hands for stretch roles; Barsh \& Yee, 2012), scholars increasingly spotlight societal factors that influence behavior and attitudes inside organizations. These factors include, social gender roles, status differences ascribed to men and women (Eagly \& Karau, 2002; Ridgeway, 2001), legislation and national cultures (e.g., Hutchings, Metcalfe, \& Cooper, 2010; Sojo, Wood, Wood, \& Wheeler, 2016). We have also witnessed a rise in governmental and institutional interventions, such as the introduction of gender quotas (Seierstad et al., 2015; Sojo et al., 2016), and mass media campaigns designed to raise gender inequity awareness and challenge traditional societal views of women's and men's capabilities and roles (e.g., Ricki, 2016). We broadly label this third era (1997-2016) as 'fix the environment'. 
Despite these gradual shifts in research focus over time, women-centered explanations for their scarcity in leadership have persisted in the workplace. In particular, men have been more likely than women to cite women-centered impediments to women's advancement such as their lack of general management or line experience ( $82 \%$ men vs $47 \%$ women; Ragins et al., 1998) and competing work-family priorities ( $61 \%$ men vs $22 \%$ women; Sanders et al., 2011). We surmise that the slower shift in practice than in academia, from individual to non-individual explanations for women's scarcity in leadership, partially reflects the knowledge - practice gap and a resistance to change (Noon, 2010). In a context in which individual explanations for impediments to women's career advancement persist, women's reliance on populist career advice begins to make sense.

The career advice literature for women is vast. There are over 3,500 books available in English on Amazon in the 'women \& business' category alone (https://www.amazon.com/Women-Business-Investing-Books/b?ie=UTF8\&node=355578011). Other similar categories are, for example, 'feminist theory' and 'women's issues.' Sandberg's book (2013) is ranked in more than one category and stands out as a contemporary example of the popularity of this genre of book. The book is, by and large, for women who are looking to climb the corporate ladder. Almost three million copies of the 'Lean In' book had reportedly been sold as of July 2016 (Swisher, 2016). Further, by 2018 the Lean In organization claimed 35,000 Lean In circles in 160 countries (https://leanincircles.org/). Overall, the popularity of Sandberg's (2013) 'Lean In' book and 'Lean In' circles attest to women's engagement with, and determination to succeed in, their careers.

Sandberg's (2013) 'Lean In' book provides a compelling, accessible, and somewhat datadriven account of the biases and obstacles that women encounter at work and at home. In doing 
so, the book partly fills a gap in the transfer of selective scholarly knowledge into practice (Bansal, Bertels, Ewart, MacConnachie, \& O'Brien, 2012). For example, Sandberg (2013) draws on scholarly research to name career challenges women experience. Some of the common career challenges covered and named in 'Lean In' are 'sex-role stereotypes', (e.g., men are the breadwinners and women are the care givers); the 'double-bind' (i.e., women are expected to be decisive and assertive, in line with their roles of 'manager' or 'leader,' but also consultative and gentle, in line with social expectations of women as nurturers), and the 'double-shift' (i.e., the time that women spend fulfilling family responsibilities in addition to the time they spend at work). Issue-naming is important in spotlighting systemic obstacles to women's advancement and in providing a common vocabulary for women and men to converse about those issues (Meyerson \& Fletcher, 2000).

Further, as women experience a myriad of barriers to advancement in the workplace, selfdoubts and 'downward adjustments' of personal career aspirations can occur (Horner, 1972; Metz, 2011). Books such as 'Lean In' counter-balance such self-doubt by offering insights into women's career challenges that inspire rather than discourage. For example, Sandberg explains in Chapter 3 ('Success and Likeability,' pp.39-51) how women's behaviors at work are constrained by social expectations; behaviors that are accepted in men but are criticized in women, such as negotiating a salary or failing to assist a co-worker. From the working woman's perspective, this information enables balanced interpretations of her career experiences.

In sum, the popular 'women \& business' literature is a form of consciousness-raising that can provide additional encouragement for women to take individual action to advance their careers. The question is can individual action stimulate career opportunities for women? 
Ragins and Sundstrom's (1989) conceptual framework of gender and power in organizations depicts three levels of influence that surround the individual level: interpersonal, organizational and societal. Sandberg's (2013) solutions to the scarcity of women in leadership place the onus on individual women to rectify the status quo. Yet, Ragins and Sundstrom (1989) describe the outer layers as exerting greater influence on the inner layers than vice versa; that is, factors at the individual level are the least influential. We use a modified version of Ragins and Sundstrom's (1989) framework to outline the influence that women's actions (individual level factors) might exert on interpersonal, organizational and societal levels (see Figure 1). As illustrated in Figure 1, barriers that are outside of women's control persist, such as mentoring, networking and subordinate support at the interpersonal level, hiring and promotion practices that favor the 'prototype' of a suitable candidate at the organizational level, and social gender roles at the societal level (Kulik \& Metz, 2017; Phelan, Moss-Racusin, \& Rudman, 2008). Thus, Sandberg's information sharing and advice to women is only one component of a more holistic approach to achieving gender equity in leadership. Nevertheless, the increasing awareness of gender inequity in leadership likely helps women's individual actions bear fruit.

(Insert Figure 1 about here)

\section{Social Awareness of Gender Inequity in Leadership}

There is increasing public interest in the scarcity of women in organizational, political and judicial leadership; a social phenomenon in which the media undoubtedly plays a key role (Bandura, 2004). Current media attention on gender issues is constant, fuelled by national and international events such as the introduction of quotas for women on boards of directors in Norway in 2008, Malala Yousafzai's attempted assassination in 2012 for advocating for Pakistani girls' education, and public advocacy for gender equity by influential men such as 
Canadian Prime Minister, Justin Trudeau (e.g., Gray, 2016a) and the $44^{\text {th }}$ President of the United States, Barack Obama (e.g., Gray, 2016b). Media coverage of such occurrences likely increases social awareness of gender issues at work and in society, and raises expectations of greater gender equity in leadership.

\section{The Influence of Individual Action on Interpersonal, Organizational and Societal Factors}

Self-confidence, self-selection and career aspirations are some of the individual factors that explain gender differences in career advancement (Fernandez-Mateo \& Fernandez, 2016). Thus, Sandberg's advice to women to overcome their own internal barriers to career advancement and 'Lean In' reflects the potential of individual factors (e.g., women's self-confidence) to affect interpersonal ones (e.g., supervisors' perceptions of women's leadership potential).

While Sandberg's advice to women is not new, the ways in which women and their actions are interpreted and perceived by significant others might be, partly due to the raised social awareness of gender inequity in leadership. Significant others encompass co-workers, supervisors, networks, subordinates, family and friends (see Figure 1). For example, we have long been aware of the benefits for women of having a mentor (e.g., Ragins \& Cotton, 1999; Wallace, 2001) and of their difficulties in finding one (Ragins \& Cotton, 1991). Yet, women acting on Sandberg's advice to cultivate mentoring relationships should encounter fewer challenges today than in the past. This is partly because some influential men have increased their efforts to mentor women and have publicly encouraged others to follow. For example, Hockridge introduced the CEO Mentor Program, whereby selected women shadowed him for four months, during his tenure as $\mathrm{CEO}$ at Aurizon (Australia's largest rail freight operator; Hockridge, 2016). 
In addition, by influencing change in their own organizations, women's individual agency potentially influences change in other institutions. This indirect influence occurs through 'mimetic processes' or the tendency of less successful organizations to copy salient aspects of more successful ones (Di Maggio, 2001). Thus, women can influence change in their own and other organizations through the advice they offer their CEOs and other key decision-makers.

Finally, the influence of women's individual action on society is reflected in the changing composition of gender equity advocacy groups. Women have long participated in advocacy groups for gender equity. An example is the Women's Social and Political Union, a group of women activists established in 1903 to advocate for women's enfranchisement in England (Pankhurst, 2015). As women-only groups contributed to raising social awareness, men-only and mixed-gender groups have emerged more recently. For example, the ' $22 \mathrm{~s}$ ' is a men-only student club at Wharton (the University of Pennsylvania's business school) established in 2014 to focus on gender inequity in pay (McGregor, 2015). In a similar vein, the 'Male Champions of Change' (MCC) is a group of highly influential male leaders formed in 2010 in Australia to keep gender equity in leadership at the forefront of the national agenda (Metz \& Kulik, 2016).

The above illustrates how women's individual agency can contribute to their career advancement by influencing change at the interpersonal, organizational and societal levels. This rationale aligns with the literature on tempered radicalism. Put simply, 'tempered radicals' are individuals who work within the system to progressively influence positive change in organizations (Meyerson, 2008). This rationale also aligns with analyses of the impact of individual action on the broader gender equality regulatory environment (Kaine, 2016). Nevertheless, we caution that individual action alone cannot fully counteract or overcome the 
multiple obstacles to gender equity at the outer levels (shown in Figure 1). Achieving gender equity in leadership requires more than just women's actions.

In sum, in this paper we examine an overlooked phenomenon: the popularity of self-help books with individually-focused career advice for women, alongside the accumulation of research evidence on the rigid barriers to women's advancement which lie outside of their control. We present a broad comparison of the populist and academic literatures to explain, from a woman's perspective, the appeal of self-help books. As such, we provide gender diversity scholars with insights into the self-help 'women \& business' literature. In addition, we update our understanding of the potential of individual women and highly-influential decision-makers to effect gender equity change. By examining the popularity of self-help books, we also contribute to the increasing awareness of the need to close the knowledge-practitioner gap and offer, in the next section, some suggestions in this regard.

\section{IMPLICATIONS FOR RESEARCH AND THE RESEARCH-PRACTICE GAP}

There are two key messages from our examination. First, the prospect of personal agency offered in self-help books, such as 'Lean In,' is appealing because it offers hope and empowers women to attempt to control their own fate (Baumgardner \& Richards, 2000). Second, it is possible that contextual factors are now more favorable to women's individual action than in the past. However, individual action alone cannot fully overcome the multiple obstacles to gender equity at the interpersonal, organizational and social levels. Thus, we do not endorse a return to a 'fix the women' research focus. Nevertheless, we draw inspiration from the popularity of these books in proposing a future research agenda.

Populist career advice can be misleading because of its narrow focus. We call for new research to counterbalance this advice. By focusing on personal strategies to career success, 
populist literature provides a simplistic view of the role played by women in shaping their own careers. Populist literature also places the burden to overcome obstacles to career success on women, thus exonerating colleagues, decision-makers, organizations and societies of their responsibility to contribute to the removal of barriers to women's advancement. Thus, in light of the appeal of self-help books for women and of changing societal factors, future research can benefit from re-examining the relative influence of individual, interpersonal, organizational and societal factors on women's advancement (see e.g., Metz \& Tharenou, 2001; Tharenou et al., 1994). New large-scale, longitudinal quantitative studies, conducted in conjunction with qualitative work, can provide valuable contemporary insights. Such leading-edge knowledge might clarify the effectiveness of future action at each of the four levels and, thus, assist women to place self-help career advice within a broader framework. It might also assist decision-makers, organizations and governments in developing effective people management policies and practices.

Populist career advice can also be misleading because it often lacks rigour. For example, authors might selectively cite evidence-based literature that supports their view. Further, the advice in the self-help literature is frequently based on the experiences of a few successful women. Through this method, populist literature does not control for alternative explanations of career success. Also, as there is no control or comparative group, populist literature cannot identify what distinguishes female career achievers from their male counterparts, and from female and male individuals who do not realize their career goals. Furthermore, most of this literature relies on female leaders' recollections of events to offer retrospective accounts of their pathways to success. Thus, further research in this area is required to add rigour to the appealing, but potentially misleading, career advice that flows from these methodologies. For instance, 
longitudinal and qualitative studies of women's and men's careers would contribute to our understanding of (1) why all or part of the advice works for some women but not for others; (2) what advice is applicable to both men and women with similar career goals; and (3) what advice is differentially applicable to women and men, and in what circumstances.

These two future research suggestions align with Chrobot-Mason, Hoobler and Bruno's call (in this issue) for '... scholars to conduct new research to explore some of the arguments for which Lean In lacks empirical support ...' (p. TBA). In their calls for this research, ChrobotMason and colleagues offer specific examples of areas in which future research can fill the evidence-based gap, such as research into how we can '... help young women become more resilient in the face of negative messages, to develop a secure, self-affirming mindset.' (p. TBA).

In addition, the self-help career advice literature is written for, and is mostly read by, women. There is no equivalent self-help literature for men. Yet, career research and self-help books for men might be beneficial to men who yearn for work-life balance, but feel constrained in utilizing enabling HRM practices. These constraints derive from, for example, social expectations and fear of negative work outcomes (Hughes \& Bozionelos, 2007). Self-help books for men would also be valuable in explicating the benefits for men of gender diverse workplaces. For example, family friendly workplace practices [FFWP] can positively influence firm outcomes, and firms with a higher proportion of female managers tend to have more FFWP (Ali, Metz \& Kulik, 2014; Bloom, Kretschmer, \& Van Reenen, 2011; Kulik \& Metz, 2017). Thus, self-help career advice for men may encourage some men to pursue their work-life preferences while assisting others to lower their resistance to gender equity in leadership.

As we previously highlighted, a gender gap exists in the understanding of the factors which hinder women's career advancement. Men are more likely than their female colleagues to 
attribute women's lack of career advancement to women (Ragins et al., 1998; Sanders et al., 2011). Men are also more likely to be content with the status quo and to resist gender equity interventions (Jordan, 2016; Kidder, Lankau, Chrobot-Mason, Mollica, \& Friedman, 2004; Noon, 2010; Thomas, Cooper, et al. 2017). Thus, future interdisciplinary research into gender, careers and change in organizations might enhance our understanding of how to increase men's felt need for gender equity and reduce male backlash to organizational gender equity initiatives. As men comprise a marked proportion of the workforce, and dominate the senior levels of organizations, their commitment is key to successful gender equity change.

This interdisciplinary research suggestion supports Arnold and Loughlin's call (in this issue) for individuals in influential positions, who are mostly men, to prioritize gender equity in organizations. As they illustrate in their paper, and as we do in ours, some highly-placed male decision-makers already advocate, and act as role models, for gender equity. However, the legitimate position power of such individuals alone is insufficient to overcome many men's (and some women's) resistance to gender equity change (Gray \& Boyd, 2016; Thomas, Cooper, et al. 2017). As a result, gender equity initiatives may be short-lived as their champions leave.

Research that spans several literatures, such as women in management, men and masculinities, work and family, and labour economics may contribute to addressing the question of how to gain men's support, so that any change in women's representation in leadership is sustainable.

Still in the vein of sustainable gender equity change, we suggest that future research is undertaken into the preservation and transfer of accumulated gender diversity management knowledge and skills in organizations. The purpose of this future research stream is to lower resistance to gender equity change programs by sharing codified organizational knowledge (e.g., lessons learnt and best practices) with everyone in the organization. The accumulation of gender 
equity knowledge can occur at the individual, work group, and organizational level. In some instances, understanding of gender inequity in organizations evolves as a result of personal and work experiences over time (Metz \& Kulik, 2016). However, the knowledge that resides in the individual is an organizational resource that likely dissipates when s/he leaves. Logically, this loss of individual-level gender equity knowledge has the potential to deplete knowledge at the work group and organizational levels. Thus, individual-level gender equity knowledge needs to be preserved to avoid the organizational costs of repeated cycles of learning. Such costs might be the under-utilization of female talent, or difficulties in attracting and retaining women. Some organizational knowledge transfer already occurs in the form of employee induction, orientation and training programs. Such transfer approaches are not, however, always effective (Kidder et al., 2004). More research into the preservation and transfer of gender diversity management knowledge and skills in organizations might assist in this regard.

Further, the popularity of the advice on strategies for women to 'survive' and succeed in today's workplace suggests that future research into a new work model would be beneficial. The prevalent work model was designed by men for men (Acker, 1990); hence the coinage 'male model of work.' This work model is characterized by long work hours, little flexibility, and uninterrupted careers (Cooper \& Lewis, 1999), and it will prevail as long as there are enough sufficiently talented individuals who can shape their lives to align with it. As such, populist advice is likely to continue to be useful to only a small proportion of women. Thus, future research into, and case studies of, more 'gender-neutral' work models is urgently needed (e.g, see Ely and Meyerson [2010] for a case study on work model change). 
The popularity of self-help books tells us that there is an ongoing need for career advice for women who aspire to climb the corporate ladder. This popularity also suggests that the growing evidence-based diversity and inclusion literature is, in general, failing to reach women and significant others. It stands to reason that there is more that we (scholars) can do, or do differently, to close the persistent knowledge-practice gap; a gap that is regularly spotlighted (e.g., Bansal et al., 2012; Phan \& Wright, 2016). Chrobot-Mason and her colleagues (in this issue) also acknowledge this gap. Specifically, they mention the need for us 'as scholars to communicate to others the many misperceptions that superiors have about the women who report to them and how these serve to negatively impact women's career paths' (p. TBA).

Scholarly knowledge transfer efforts already occur, for example, via regular media commentaries, presentations at industry or corporate events, research partnerships with government agencies and organizations, and books (e.g., Eagly \& Carli, 2007). It is, however, insufficient to transfer our research findings once or twice. In an era of super-connectivity and information flow, it may also be insufficient to rely solely on our academic credentials to be heard. Thus, one lesson for scholars from the continued supply of self-help books that target working women, such as 'Lean In,' is the need to similarly continually transfer a combination of past and new knowledge to practice in novel, varied and interesting ways (e.g., through digital technology). Another is that, to be heard, we might benefit from teaming up with high-profile individuals or celebrities in our efforts to disseminate our research.

Further, the popularity of self-help books suggests that the extensive gender and careers research published in management journals is important, but mostly invisible to men and women in corporations (Bansal et al., 2012). Scholars publish their contributions to knowledge in journals that count for performance and tenure evaluation processes (Phan \& Wright, 2016). 
Such publication approach disseminates scholarly knowledge mostly among academics and students (through our teaching). Practitioners are more likely to rely on books or social media than on academic journals for knowledge acquisition, because they are accessible and rich in 'how to' detail and day-to-day examples. However, books, posting summaries of key research on blogs, writing a weekly or monthly column in a newspaper or online publication, creating 'podcasts' that can be freely downloaded and listened to, and other knowledge dissemination channels are often under-valued in the academic evaluation processes of many of the institutions we work in (Adler \& Harzing, 2009). As a result, only a sliver of academic research gets to market in a timely manner, and influences individuals in organizations directly or indirectly by informing human resource management policies and practices. We thus echo calls for our academic institutions to show a greater appreciation of knowledge dissemination efforts that enhance the accessibility of academic research (e.g., Adler \& Harzing, 2009).

Moreover, part of making research relevant to practitioners involves providing recommendations that are novel and actionable. Many of the practical implications in academic journal publications are too broad to be useful guides to practice. Although academic publications are not written for managers, future research will nevertheless benefit from greater attention to the practical implications for enhanced relevance to practitioners and ease of implementation. In the words of Wright and Phan (2017) 'those details can be terribly consequential to ordinary citizens in their daily lives' (p.1).

\section{CONCLUSION}

We reflect in this paper on the popularity of the self-help literature containing career advice for women who aspire to leadership. In particular, we assume the working woman's perspective. We conclude that there are advantages and disadvantages in women's reliance on populist 
literature. The two main advantages are information transfer and female empowerment. Populist books inform by using a combination of anecdotal and scholarly information that, albeit selective, may help women who want to advance in management to make some sense of their often frustrating work experiences. Populist books also empower women by offering career advancement strategies that are within the individual's control. The two main disadvantages of this book genre are the perpetuation of myths (e.g., that the problem resides with women) and their subsequent detrimental effect on gender equity change efforts. An example of a detrimental effect is the organizational cost in implementing initiatives that focus on 'fixing the women' for little or no change in their representation in leadership. Thus, we recommend that scholars engage in, and their institutions reward, efforts that broaden the scope and enhance the rigour of the information that professional women, and their potential supporters, currently consume.

We hope that this paper reaches academic and non-academic audiences, and stimulates further discussion. Our paper, and others in this issue, illustrate how the popularity triggered by one book aimed at career women suggests research areas for scholars. Some scholars may be trying to crystallize their views about the contribution to knowledge of the populist genre of selfhelp books on career advice for women; others may be seeking to enhance that contribution. It is possible that, directly or indirectly, our paper will ultimately be useful to women's career advancement via the research that it will instigate, the detailed practical implications that it will encourage, and the student audiences that it will inform. 


\section{References}

Acker, J. (1990). Hierarchies, jobs, bodies. Gender and Society, 4, 139-158.

Adler, N. J., \& Harzing, A. W. (2009). When knowledge wins: Transcending the sense and nonsense of academic rankings. Academy of Management Learning \& Education, 8(1), 7295.

Alexander, R., \& Sapery, E. (1973). The shortchanged: Women and minorities in banking. New York: Dunellen Publishing Company, Inc.

Ali, M., Metz, I., \& Kulik, C. T. (2015). The impact of work-family programs on the relationship between gender diversity and performance. Human Resource Management, 54, 553-576.

Bandura, A. (2004). Social cognitive theory for personal and social change by enabling media. In A. Singhal, M. Cody, E. M. Rogers, \& M. Sabido (Eds.) Entertainment-education and social change (pp. 75-96). Mahwah, New Jersey: Lawrence Erlbaum Associates.

Bansal, P., Bertels, S., Ewart, T., MacConnachie, P., \& O'Brien, J. (2012). Bridging the research-practice gap. The Academy of Management Perspectives, 26(1), 73-92.

Barsh, J., \& Yee, L. (2012). Unlocking the full potential of women at work. McKinsey \&

\section{Company/Wall Street Journal.}

Baumgardner, J., \& Richards, A. (2000). Manifesta: Young women, feminism and the future. New York, United States: Farrar, Straus \& Giroux Inc.

Becker, G. S. (1993). Human capital. Chicago: The University of Chicago Press.

Bloom, N., Kretschmer, T., \& Van Reenen, J. (2011). Are family-friendly workplace practices a valuable firm resource? Strategic Management Journal, 32, 343-367.

Catalyst Quick Take. (2017). Women in management. Accessed at http://www.catalyst.org/knowledge/women-management. 
Chao, G. T., Walz, P., \& Gardner, P. D. (1992). Formal and informal mentorships. Personnel Psychology, 45, 619-636.

Cooper, C. L., \& Lewis, S. (1999). Gender and the changing nature of work. In G. Powell (Ed.). Handbook of gender and work (pp. 37-46). California: Sage Publications.

Dezsö, C., \& Ross, G. (2016) Is there an implicit quota on women in top management? A largesample statistical analysis. Strategic Management Journal, 37, 98-115.

Di Maggio, P. 2001. The twenty-first century firm. New Jersey: Princeton University Press.

Eagly, A. H., \& Carli, L. L. (2007). Through the labyrinth. Harvard Business Press.

Eagly, A. H., \& Karau, S. J. (2002). Role congruity theory of prejudice toward female leaders. Psychological Review, 109, 573-598.

Eagly, A. H., \& Steffen, V. J. (1984). Gender stereotypes stem from the distribution of women and men into social roles. Journal of Personality and Social Psychology, 46, 735-754.

Ely, R. J., \& Meyerson, D. E. (2000). Theories of gender in organizations: A new approach to organizational analysis and change. Research in Organizational Behavior, 22, 103-151.

Ely, R. J., \& Meyerson, D. E. (2010). An organizational approach to undoing gender: The unlikely case of offshore oil platforms. Research in Organizational Behavior, 30, 3-34.

Fernandez-Mateo, I., \& Fernandez, R.M. (2016). Bending the Pipeline? Management Science, 62, 3636-3655.

Gray, E. (2016a). Justin Trudeau: I'll Keep Saying I'm A Feminist Until There's No Reaction. The Huffington Post, March 26. Accessed at http://www.huffingtonpost.com.au/entry/justintrudeau-feminism-fatherhood_us_56f448a1e4b014d3fe22a29f

Gray, E. (2016b). Barack Obama wrote an essay about feminism every man needs to read. The Huffington Post, August 8. Accessed at http://www.huffingtonpost.com.au/entry/barackobama-feminist-essay-mic-drop_us_57a33599e4b0e1aac914d926. 
Hausmann, R., Tyson, L. D., Bekhouche, Y., \& Zahidi, S. (2014). Gender gap report 2014. Geneve: World Economic Forum.

Hockridge, L. (2016). Why inequality can't be treated equally, The AusIMM Bulletin, posted June, https://www.ausimmbulletin.com/feature/why-inequality-cant-be-treated-equally/ Horner, M. S. (1972). Toward an understanding of achievement-related conflicts in women. Journal of Social Issues, 28, 157-175.

Hughes, J., \& Bozionelos, N. (2007). Work-life balance as source of job dissatisfaction and withdrawal attitudes. Personnel Review, 36(1), 145-154.

Hutchings, K., Metcalfe, B., \& Cooper, B. K. (2010). Exploring Arab Middle Eastern women's perceptions of barriers to, and facilitators of, international management opportunities. The International Journal of Human Resource Management, 21(1), 61-83.

Jordan, A. (2016). Conceptualizing Backlash: (UK) Men's Rights Groups, Anti-Feminism, and Postfeminism. Canadian Journal of Women and the Law, 28(1), 18-44.

Joshi, A., Neely, B., Emrich, C., Griffiths, D., \& George, G. (2015). Gender research in AMJ. Academy of Management Journal, 58, 1459-1475.

Kaine, S. (2016). Women, work and industrial relations in Australia in 2015. Journal of Industrial Relations, 58, 324-339.

Kanter, R. M. (1977). Some effects of proportions on group life: Skewed sex ratios and responses to token women. American journal of Sociology, 82, 965-990.

Kidder, D. L., Lankau, M. J., Chrobot-Mason, D., Mollica, K. A., \& Friedman, R. A. (2004). Backlash toward diversity initiatives. International Journal of Conflict Management, 15(1), 77-102. 
Kulik, C. T., \& Metz, I. (2017). Women at the top. In S. Jackson \& M. Hitt (Eds.), Oxford Research Reviews (pp. 239). Oxford: Oxford University Press.

McGregor, J. (2015). A gender-equality club, run by men. The Washington Post. Accessed at https://www.washingtonpost.com/news/on-leadership/wp/2015/08/10/a-gender-equalityclub-run-by-men/

Metz, I. (2011). Women leave because of family responsibilities: Fact or fiction? Asia Pacific Journal of Human Resources, 49, 285-307.

Metz, I., \& Kulik, C. (2014). The rocky climb: Women's advancement in management. In S. Kumra, R. Simpson \& R. Burke (Eds.), The Oxford Handbook of Gender in Organizations (pp. 175-199). Oxford: Oxford University Press.

Metz, I., \& Kulik, C. T. (2016). Male Champions of Gender Equity Change. AOM HR Division's International Conference, Sydney: Australia.

Metz, I. \& Tharenou, P. (2001). Women's Career Advancement. Gender \& Organisation Management, 26, 312-342.

Meyerson, D. E., \& Fletcher, J. K. (2000). A modest manifesto for shattering the glass ceiling. Harvard Business Review, 78(1), 126-136.

Meyerson, D. E. (2008). Rocking the Boat. Harvard Business Review Press.

Noon, M. (2010). The shackled runner. Work, Employment and Society, 24, 728-739.

Pankhurst, S. (2015). The Suffragette. London: Courier Dover Publications.

Phan, P., \& Wright, M. (2016). Whither the academy of management Perspectives. Academy of Management Perspectives, 30(1), 1-4.

Phelan, J. E., Moss-Racusin, C. A., \& Rudman, L. A. (2008). Competent yet out in the cold. Psychology of Women Quarterly, 32, 406-413. 
Priestley, A. (2014). Why is offering flexible work still considered 'disruptive'? Women's Agenda, October 2. Accessed at http://www.womensagenda.com.au/talkingabout/item/4697-why-is-offering-flexible-work-still-considered-disruptive

Ragins, B. R., \& Cotton, J. L. (1991). Easier said than done: Gender differences in perceived barriers to gaining a mentor. Academy of Management Journal, 34, 939-951.

Ragins, B. R., \& Cotton, J. L. (1999). Mentor functions and outcomes. Journal of Applied Psychology, 84, 529.

Ragins, B. R., \& Sundstrom, E. (1989). Gender and power in organisations: A longitudinal perspective. Psychological Bulletin, 105 (1), 51-88.

Ragins, B. R., Townsend, B., \& Mattis, M. (1998). Gender gap in the executive suite. Academy of Management Executive, 12, 28-42.

Ricki (2016). ANZ claims six awards at Cannes Lions for campaigns supporting diversity and inclusion. Campaign Brief. Accessed at http://www.campaignbrief.com/2016/06/anzclaims-six-awards-at-canne.html

Ridgeway, C. L. (2001). Gender, status, and leadership. Journal of Social Issues, 57, 637-655. Ryan, M. K., \& Haslam, S. A. (2005). The glass cliff. British Journal of Management, 16, 8190.

Sandberg, S. (2013). Lean In: Women, work and the will to lead. New York: Knopf.

Sanders, M., Hrdlicka, J., Hellicar, M., Cottrell, D., \& Knox, J. (2011). What stops women from reaching the top? Accessed at https://cew.org.au/media-and-speeches/cew-research/

Schein, V. E., Mueller, R., Lituchy, T., \& Liu, J. (1996). Think manager--think male: A global phenomenon? Journal of Organizational Behavior, 17(1), 33-41. 
Seierstad, C., Warner-Søderholm, G., Torchia, M., \& Huse, M. (2017). Increasing the number of women on boards. Journal of Business Ethics, 141, 289-315.

Sojo, V. E., Wood, R. E., Wood, S. A., \& Wheeler, M. A. (2016). Reporting requirements, targets, and quotas for women in leadership. The Leadership Quarterly, 27, 519-536.

Swisher, K. (2016, July 29). Sheryl Sandberg leans into her next book, 'Option B,' about grieving and healing. Recode. Accessed at https://www.recode.net/2016/7/29/12320222/sheryl-sandberg-leans-into-next-book-optionb-about-grieving-and-healing

Terborg, J. R. (1977). Women in management. Journal of Applied Psychology, 62, 647-664.

Tharenou, P., Latimer, S., \& Conroy, D. (1994). How do you make it to the top? Academy of Management Journal, 37, 899-931.

Thomas, R., Cooper, M., Konar, E., Rooney, M., Finch, A., et al. (2017). Women in the workplace 2017. McKinsey \& Co and LeanIn. https://womenintheworkplace.com/

Treiman, D. J., \& Terrell, K. (1975). Sex and the process of status attainment: A comparison of working women and men. American Sociological Review, 40, 174-200.

Wallace, J. E. (2001). The benefits of mentoring for female lawyers. Journal of Vocational Behavior, 58, 366-391.

Wallace, S. (2014). Tackling unconscious bias in banking, HR Magazine. Accessed at http://www.hrmagazine.co.uk/hro/features/1146334/tackling-unconscious-bias-banking

Wright, M., \& Phan, P. (2017). AMP articles in an uncertain new world. The Academy of Management Perspectives, 31(1), 1-3.

Youssef, N. H. (1974). Women and work in developing societies. POPLINE. Accessed at https://www.popline.org/node/515995 
Table 1. Number of publications on women and management - illustrative

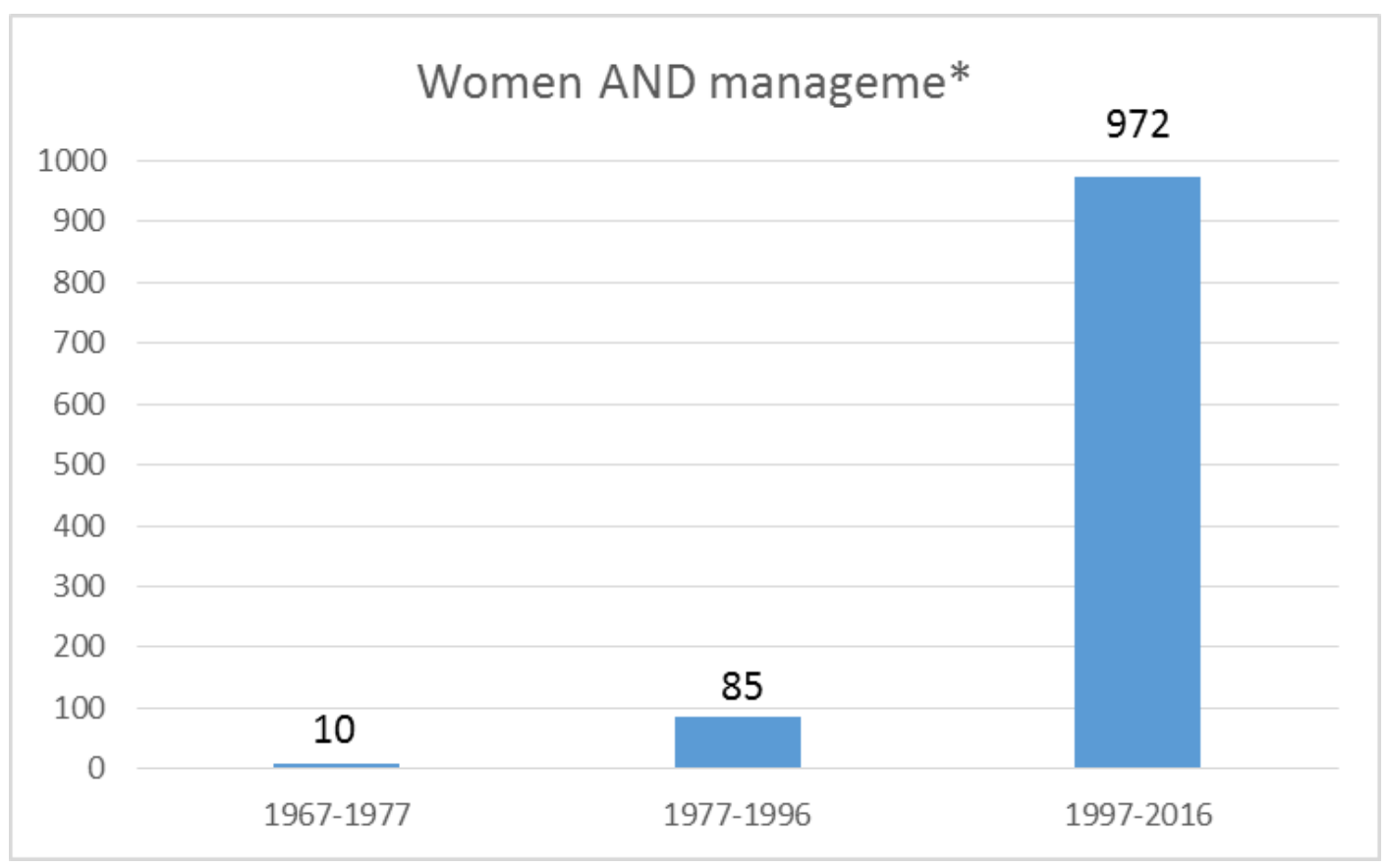

Note: This literature search was conducted on Web Of Science using keywords (Women AND Manage*). 
Table 2. Sample of research in 'women and management' over 50 years

\begin{tabular}{|c|c|c|c|}
\hline $\begin{array}{l}\text { ILLUSTRATIVE TOPICS } \\
\text { (WITHIN BROAD } \\
\left.\text { PERIODS }{ }^{1}\right)\end{array}$ & $\begin{array}{c}1967-1976 \\
\begin{array}{c}\text { Number of articles (e.g., frequently cited } \\
\text { paper/s) }\end{array}\end{array}$ & $\begin{array}{c}1977-1996 \\
\begin{array}{c}\text { Number of articles (e.g., frequently cited } \\
\text { paper/s) }\end{array}\end{array}$ & $\begin{array}{c}1997-2016 \\
\begin{array}{c}\text { Number of articles (e.g., frequently cited } \\
\text { paper/s) }\end{array}\end{array}$ \\
\hline \multicolumn{4}{|l|}{ Fix the Women } \\
\hline Personality & $\begin{array}{c}7 \\
\text { (e.g., Westbrook \& Molla, 1976; Schmidt, } \\
\text { 1970) }\end{array}$ & $\begin{array}{c}10 \\
\text { (e.g., Tharenou, Latimer, \& Conroy, 1994; } \\
\text { Melamed, 1995) }\end{array}$ & $\begin{array}{c}59 \\
\text { (e.g., Twenge \& Campbell, 2008; Forret \& } \\
\text { Dougherty, 2001) }\end{array}$ \\
\hline Education & $\begin{array}{c}47 \\
\text { (e.g., Astin, 1976; Tidball, 1976) }\end{array}$ & $\begin{array}{c}17 \\
\text { (e.g., Stroh, Brett, \& Reilly, 1992; Tharenou, } \\
\text { Latimer, Conroy, 1994) }\end{array}$ & $\begin{array}{c}136^{2} \\
\text { (e.g., Chen, Greene, \& Crick, 1998; Hillman, } \\
\text { Cannella, \& Harris, 2002) }\end{array}$ \\
\hline \multicolumn{4}{|l|}{ Fix Organizations } \\
\hline Network* & 0 & $\begin{array}{c}7 \\
\text { (e.g., Ibarra, 1992, 1995) }\end{array}$ & $\begin{array}{c}66 \\
\text { (Forret \& Dougherty, 2004; Hillman, } \\
\text { Shropshire, \& Cannella Jr., 2007) }\end{array}$ \\
\hline $\begin{array}{l}\text { Organi* AND } \\
\text { (Policies OR Practices) }\end{array}$ & 0 & $\begin{array}{c}8 \\
\text { (e.g., Chao, Walz, \& Gardner, 1992; Kerfoot, } \\
\text { \& Knights, 1993) }\end{array}$ & $\begin{array}{c}189 \\
\text { (e.g., Anderson, Coffey, \& Byerly, 2002; } \\
\text { Perry-Smith, \& Blum, 2000) }\end{array}$ \\
\hline \multicolumn{4}{|l|}{ Fix the Environment } \\
\hline $\begin{array}{l}\text { Gender AND (targets OR } \\
\text { Quotas) }\end{array}$ & 0 & $\begin{array}{c}1 \\
\text { (Kremer, Hallmark, Cleland, et al., 1996) }\end{array}$ & $\begin{array}{l}33 \\
\text { (e.g., Tatli, Vassilopoulou, \& Oezbilgin, 2013; } \\
\text { Casey, Skibnes, \& Pringle, 2011) }\end{array}$ \\
\hline National AND culture & 0 & $\begin{array}{c}1 \\
\text { (Stephens \& Greer, 1995) }\end{array}$ & $\begin{array}{l}24 \\
\text { (e.g., Parboteeah, Hoegl, \& Cullen, 2008; } \\
\text { Hutchings, Metcalfe, \& Cooper, 2010) }\end{array}$ \\
\hline
\end{tabular}

Notes: ${ }^{1}$ For period 1967-1976, literature searches included only 'Women' and 'topic' as the combination (Women AND Manage*) and a topic always resulted in zero findings. For periods 1977-1996 and 1996-2016 literature searches included (Women AND Manage*) and a topic. Topics searched are shown in the first column of Table 2. See the Appendix for detailed information on the literature searches performed.

${ }^{2}$ This increase in published studies in the last two decades include the previously under-examined areas of gender differences in education in directorships and entrepreneurships. 
FIGURE 1

Four level framework of factors that can affect working women

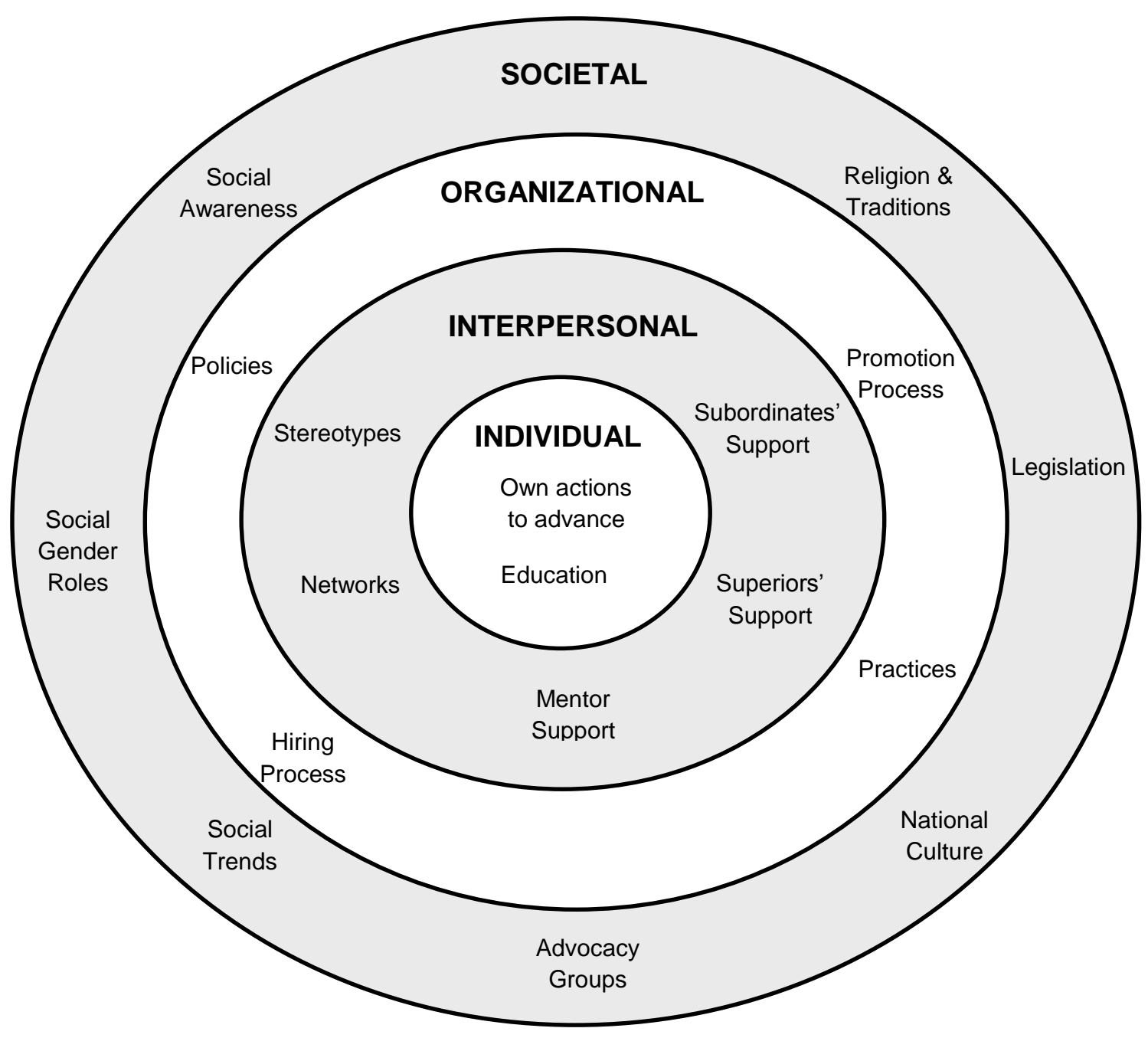




\section{APPENDIX}

Method used in literature searches

All literature searches were conducted using the Web Of Science database and restricted to the Science Citation Index Expanded (SCI-EXPANDED), Social Sciences Citation Index (SSCI), and Arts \& Humanities Citation Index (A\&HCI). All searches were also restricted to articles published in English in seven Web Of Science categories: Management, Business, Women's Studies, Psychology Applied, Industrial Relations Labor, Economics, and Education / Education Research.

The first search (applied all criteria above and) used the basic search combination (Women AND management). As can be seen from Table 2, no articles were found for the 1967-1976 period. Thus, all results reported for 1967-1976 are of searches using keywords (Women AND Topic) $)^{2}$. Columns three (1977-1996 period) and four (1997-2016 period) of Table 2 show search results using a combination of ((Women AND Management) AND Topic).

For each of the three time periods 'Topic' comprised:

- (Personality) and (Education): to illustrate research focus over time on the individual;

- $(\text { Network*) })^{3}$ and (Organi* AND (Policies OR practices)): to illustrate research focus over time on interpersonal and organization topics, respectively; and

- (Targets OR Quotas) and (National AND Culture): these two search combinations were used to illustrate research focus over time on societal factors.

So, for example, the search combination for the 1997-2016 period at the societal level used the combination: (Women AND Manage*) AND (National AND Culture).

\footnotetext{
${ }^{2}$ A subsequent search conducted for period 1967-1976 using (Women AND Management AND Topic) confirmed that there were no such articles published during 1967-1976.

${ }^{3}$ The * allows for the inclusion of words starting with 'Network', such as networks and networking; when used, the * character performed the same function in all searches.
} 


\section{Biographies}

Isabel Metz (1.metz@mbs.edu) is a professor of organisational behaviour at the Melbourne Business School, University of Melbourne. Her research interests include gender and careers, diversity and inclusion, and male advocacy for gender equity. She has held leadership positions at the Academy of Management and is on the editorial boards of several journals.

Savita Kumra (kumra@aus.edu) is associate professor in the School of Business

Administration at the American University in Sharjah. Her research interests focus on gender and its impact on the career management process, focusing on impression management, meritocracy and social capital. 